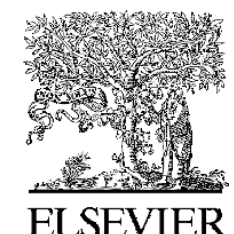

\title{
EDITORIAL
}

\section{Beta-blockers and asthma: A safe combination?}

Treatment with $ß$-blockers is very effective in patients with hypertension, heart failure and angina pectoris. In general, it has been thought that this therapy should be withheld from patients with asthma, since ß-blockers could initiate severe asthma attacks. With the development of more selective $B-1$-blockers and drugs with intrinsic sympathicomimetic activity (ISA) the applicability of these drugs in asthma should be reconsidered.

Two types of $\beta$-receptor are known. $\beta-1$ receptors are located in the heart, wheress $B . Z$ receptors are located in the aiorlys and certain vessels. B-2-recep or blockaae may cause hroncnấl obst uction ary dyspnoea, and may reduce the effecl of short- and long-acting 1 -agonists during an asthma attack.

Non-selective $\beta$-blockers have similar effects on the $B-1-$ and $B-2$ receptor. Selective $B$-blockers have a higher affinity for $\beta-1$ receptors, although selectivity is lost at higher dosages. The presence of ISA is important since such drugs do not block the B-receptor completely but also in part stimulate the receptor [1].

In the Cochrane meta-analysis [2], randomised placebo-controlled, double-blind studies of both single dose and multiple doses of ß-blockers were included with up to eight weeks on active treatment. A single dose of selective B-blocker reduced the $\mathrm{FEV} 1$ by $8 \%(\mathrm{Cl} 6.2-9.8 \%)$, and was not accompanied by complaints. The increase in FEV1 after administration of a short-acting $B$-agonist was larger in the case of $B$-blockers without ISA compared to $ß$-blockers with ISA. After prolonged use there were no differences in this FEV1 response between B-blockers with or without ISA. The course of FEV1 was not affected by both groups of $\beta$ blockers. In addition, the use of selective $B$ blockers did not increase the need for short-acting B-agonists.

However, all studies published were of relatively short duration, which is clearly different from continuous treatment for many years. More importantly, in most of these studies the strerity of asthma was not cleaily defined according to, for example, 3TS [3] UI GINA [4] guidelines. The girwa Cof patients with severe asthma may be harrowed episolichlif cor chronically. A further percient age small reduction in airway calibre may increase airway resistance four-fold. So, although evidence from studies is not available, $\beta$-blockers should not be prescribed in patients with previously severe asthma attacks, severe asthma, marked bronchial hyperresponsiveness, and/or recurrent exacerbations. There are no data on whether or not to continue $ß$-blockers during an asthma attack, but we would strongly advise discontinuing them during such episodes.

Although randomised studies supported by metaanalyses may guide the physician, one should note individual cases and reports of severe or even fatal asthma attacks which were attributed to the use of $\beta$-blockers [5-8]. Although these were mainly older reports referring to non-selective $B$-blockers, individual instruction and close follow-up (e.g. by means of frequent peak flow measurements) is needed when prescribing these drugs.

In conclusion, it appears safe to prescribe selective $ß$-blockers in patients with stable, mild to moderate asthma. Although not fully confirmed by studies, we recommend that the clinician prefers selective $B$-blockers with ISA. 


\section{References}

[1] Jakubetz J, Schmuck S, Poller U, Fuchs B, Gorf A, Radke J, Ponicke K, Brodde OE. Cardiac effects of beta-adrenoceptor antagonists with intrinsic sympathomimetic activity in humans: beta1- and/or beta2-adrenoceptor mediated? J Cardiovasc Pharmacol 1999;33:461-72.

[2] Salpeter S, Ormiston T, Salpeter E. Cardioselective betablockers for reversible airway disease. Cochrane Database Syst Rev 2002. CD002992.

[3] British Thoracic Society. British guideline on the management of asthma. Thorax 2003;58 (Suppl. 1):i1-94.

[4] National Institutes of Health and National Heart, Lung and Blood Institute. Global Initiative for Asthma. 2002.

[5] McNeill RS. Effect of a beta-adrenergic-blocking agent, propranolol, on asthmatics. Lancet 1964;13:1101-2.

[6] Zaid G, Beall GN. Bronchial response to beta-adrenergic blockade. N Engl J Med 1966;275:580-4.

[7] Anderson EG, Calcraft B, Jariwalla AG, Al-Zaibak M. Persistent asthma after treatment with beta-blocking agents. Br J Dis Chest 1979;73:407-8.
[8] Jones K, Berrill WT, Bromly CL, Hendrick DJ. A confidential enquiry into certified asthma deaths in the North of England, 1994-96: influence of co-morbidity and diagnostic inaccuracy. Respir Med 1999;93:923-7.

P.N.R. Dekhuijzen*

K. Artan

Department of Pulmonary Diseases

Radboud University Nijmegen

Medical Centre, P.O. Box 9101

6500 HB Nijmegen, The Netherlands

*Corresponding author. Tel.: +31 243614579

fax: +31243610324

E-mail address: r.dekhuijzen@long.umcn.nl

(P.N.R. Dekhuijzen)

15 July 2005

\section{Available online at www.sciencedirect.com \\ science $\boldsymbol{d}$ Direct.}

\section{Available online at http:/www thepcriorg}

